\title{
10 Revisiting the Emic Perspective: Lessons to Be Learnt from the Worldly-Other-Worldly Distinction in Tibet and Beyond
}

\subsection{Introduction}

The "worldly-other-worldly" division (Sanskrit: laukika-lokottara) is usually presented as a contrastive opposition of Indic origin, frequent reference to which occurs in various Buddhist textual traditions. In general terms, this binary division seeks to delineate the other-worldly or transmundane - i.e. "something that is related to attaining liberation (vimokșa) from samsāra or that leads to such liberation" (Buswell and Lopez 2014, 481) - seen to lie at the heart of the Buddhist doctrine, from areas that are judged as "mundane." Thus, according to traditional literature, the spiritual path of the true renunciate, along with the ideals and goals that inspire it, belong to an order that transcends the everyday affairs of human society. The scheme has attracted considerable academic attention, and has been dealt with at length by Seyfort Ruegg (2008) particularly in relation to India and Tibet. ${ }^{1}$

On at least three counts this division seems notable. Firstly, this is an emic distinction, thus whatever controversies there might be regarding the validity and applicability of various western theoretical and metatheoretical frameworks, it at least seems to be an account from within the culture. Secondly, as with numerous other translated terms and categories, this division is commonly referred to in Buddhist writings from a variety of territories and times. However, the significant doctrinal, historical, and social dimensions to this division elaborated on

1 I wish to thank Berthe Jansen, Markus Viehbeck, and Birgit Kellner for the comments and suggestions that they made regarding draft versions of this work. I am especially grateful to Birgit Kellner for her shrewd observations, from which this study has much benefitted.

Note: Research for this article was conducted within the subproject "Buddhism between South Asia and Tibet - Negotiating Religious Boundaries in Doctrine and Practice" of the interdisciplinary research group "Negotiating Religion From a Transcultural Perspective" at the Cluster of Excellence "Asia and Europe in a Global Context - The Dynamics of Transculturality," University of Heidelberg.

Ә Open Access. (C) 2019 Jonathan Samuels, published by De Gruyter. (cc) BY-NC-ND This work is licensed under a Creative Commons Attribution-NonCommercial-NoDerivatives 4.0 International License.

https://doi.org/10.1515/9783110413083-010 
below indicate that it has had far more currency than the majority of these shared items, the impact of which has largely been confined to the domains of literature and traditional scholarship. The worldly-other-worldly distinction is what might conventionally be described as "cross-cultural." 2 It might also, in the view of some, deserve to be regarded as a "transcultural phenomenon," especially if one understands transculturality as referring to something that traverses of linguistic, ethnic, and territorial boundaries, and can fruitfully be examined in terms of its border-crossing aspects. Lastly, although this scheme is one that has been promoted by religious thinkers and writers, its application has been diverse. The "worldly" side of the division evidently embraces many aspects of what would commonly be judged "secular." As such, the division seems to promise insights into how relations and boundaries between the religious and non-religious domains have been negotiated in different cultural contexts.

In traditional texts the worldly-other-worldly division is generally treated as self-evident, or explained in terms of a foundational myth. Many academics, on the other hand, feel compelled to lift this binary from its original cultural setting(s), and interpret it in terms of a "bigger" theoretical picture. Previous studies have often sought to frame discussion of the division within, or use it as a point of departure for, engagement with the broader themes of the religioussecular divide.

\subsection{Studies of the Emic Division}

The worldly-other-worldly division is relevant to larger debates about religion in pre-modern Asia. It has been argued, particularly in discussions informed by post-colonial theory (McCutcheon 1997, 1998), that the division between the religious and secular spheres is one that has been projected onto spatially and/or chronologically remote cultures. ${ }^{3}$ More generally, it has also been asserted that "religion" is a non-native term, "created by scholars for their intellectual purposes" (Smith 1998, 281). However, Kleine has asserted, with respect to medieval Japan (2013, 2-8), that the worldly-other-worldly division represents persuasive evidence of a clear, self-conscious distinction between religious and

2 Terms for the worldly are Pāli: lokiya; Chinese: shijian; Japanese: seken; Korean: segan; Tibetan: 'jig rten. Those for the other-worldly are Pāli: lokuttara; Chinese: chushijian; Japanese: shusseken; Korean: ch'ulsegan; Tibetan: 'jig rten las 'das pa (Buswell and Lopez 2014, 467-468, 481).

3 For further discussion on this issue see Kleine (2013, 2-9). 
secular spheres, at least when one is prepared to judge the terms or concepts involved as "functional equivalents" $(2013,7)$.

Some form of worldly-other-worldly distinction might be seen as integral to a Buddhist view of the universe, and a strong link exists between this distinction and the most fundamental binary division of nirvāna and samsāra: a division which "may in fact be described as the oldest emic secondary encoding by which the more general guiding distinction transcendent (lokottara)/immanent (laukika) is specified from a soteriological perspective" (Kleine 2013, 15). ${ }^{4}$ As demonstrated in two of its most common applications - governance and interreligious relationships (discussed below) - the worldly-other-worldly scheme seems regularly to have been employed in attempts to navigate relations between religious ideal and social reality. Where the designations samsāra and the samsāric have been used, the message is generally uncompromising: these are things to be shunned. In contrast, the term "worldly" has commonly seemed to recognise the provisional necessity (even for those seeking liberation) of various aspects of the mundane. Thus, the worldly-other-worldly division has often "served as an organizing principle for ordering a complex world of religious and cultural representations” (Seyfort Ruegg 2008, 40).

The Pāli (lokiya-lokuttara) and Sanskrit (laukika-lokottara) versions of the worldly-other-worldly division were obviously earlier formulations than those that eventually appeared in China, Japan, Tibet, and elsewhere. Questions remain about the origins and relation between these two. ${ }^{5}$ However, it was obviously the prevalence of Theravāda or Mahāyāna Buddhism (with their respective canons and literatures) that determined which of the two was primarily referenced in any given geographical area or cultural setting. The Pāli language version (i.e. lokiya-lokuttara) has been discussed, among others, by Ames (1964), Southwold (1978; 1983), and Holt (1991, 19-26), especially in the Sinhalese context, whereas Tambiah has considered the division in the Thai setting (1970, 40; 1976, 9, 41-43). Most of these works adopt an anthropological approach and a synchronic perspective regarding the scheme. It is furthermore sometimes used in support of the distinction between a "great" and "little"

4 Aspects of this touch upon the systems theory promoted by Luhmann, which Kleine has connected with the worldly-other-worldly distinction (see below).

5 Gombrich seems to dismiss the idea that Pāli has some prior claim to these terms by asserting that they are "pure Sanskrit" $(1971,58)$. He also identifies this as a scholarly division (1971, 58). This statement may be as much about the community that has greatest use for the division as about its origin. But it should be noted that Southwold, who like Gombrich worked in Sri Lanka (although a different area), reports that the division enjoys widespread usage even on village level $(1983,77)$. 
tradition - i.e. the division between monastic Buddhism and village Buddhism. Many in the social sciences treat the analytical framework of dualistic oppositions as an essential way to approach explorations of the ritual, social, and other domains. As explained below, discussions about the worldly-otherworldly regularly compare and dispute its relationship with western bipartite divisions.

Regarding the Sanskritic branch of the worldly-other-worldly division (and its various offshoots), apart from the other studies cited below, special mention should be made of Seyfort Ruegg's work on the topic. Based chiefly on Sanskritic sources, particularly in relation to the interface with Tibet, his interest in the division culminated in his detailed study of 2008, entitled, The symbiosis of Buddhism with Brahmanism/Hinduism in South Asia and of Buddhism with 'local cults' in Tibet and the Himalayan region. Some of the themes Seyfort Ruegg deals with have some relevance to contemporary or recent practices, but in line with others who concentrate on the (Sanskritic) laukika-lokottara, he examines it mainly through the medium of historical religious literature. Some of the points he makes regarding Tibet are considered below.

\subsection{A Cross-Cultural Division}

Before examining some more specific points regarding the use of the worldlyother-worldly division in the Tibetan situation, it is worth discussing two areas in which the division has been most commonly cited. These are: 1. Governance, and 2. Interreligious relationships. As well as illustrating ways that the division has been used in different contexts, this discussion will highlight some of the correspondences that seem to support the idea that the division be viewed as a single, cross-cultural phenomenon.

\subsubsection{Governance}

A chief paradigm in Buddhist literature for developing some concept of a secular domain - in contrast with a spiritual one - is the description of duties of the dharmarāja ("righteous king"). The worldly-other-worldly distinction seems regularly to have been employed as a way of circumscribing dual domains, often characterised as "secular" and "religious." Tambiah deals at length with the latter divide, providing Pāli and Sanskrit literary sources, and explores the concept in the context of the Thai monarchy, an institution he proposes is to some extent based upon the worldly-other-worldly divide (Tambiah 1976, 9, 41). Vital to the 
understanding of the dual domains is the presence of parallel jurisdictions and rules, or codes of law. Kleine suggests that certain areas of discourse in medieval Japan were organised around the binary code of the "ruler's law" $(\bar{o} b \bar{o})$ and "Buddha's law" (buppō). He quotes the prominent figure Rennyo (1415-1499), the "second founder of Jōdo Shinshū," as one who links the two systems with the worldly (seken) and other-worldly division (shusseken) (2013, 23). Kleine talks of a "ōbo/buppō dichotomy," and shows how medieval writers developed the concept of an "interdependence of the ruler's law and the Buddha's law" (ōbo buppō sōi). He proposes that this interdependence represents more than mere cooperation between state and "church" institutions, and should be interpreted as a dichotomy that is a "culturally specific emic variation of the religious/secular distinction" (Kleine 2013, 23).

Even though aspects of the dichotomy may be specific to the Thai or Japanese situations, there are interesting parallels with Tibet. The notion of the division between spiritual (chos) and temporal (srid) orders, and particularly the "union" of these (chos srid zung 'brel) was put forward as the ideal system for governance by the Fifth Dalai Lama (Ngag dbang blo bzang rgya mtsho 1617-1682) at the foundation of the dGa' ldan pho brang administration (Cüppers 2004, 8). Much earlier, there are specific references to the worldly-other-worldly division in relation to dual jurisdictions and codes of law. Very similar formulations to the Japanese ones appear: the "ruler's law" (rgyal khrims) and the "religious law" (chos khrims). It is again the worldly-other-worldly division that is cited in support of this distinction. $^{6}$

More specifically, the worldly-other-worldly (Tibetan: 'jig rten-’jig rten las 'das pa) has served as a key framework within a genre of literature which takes governance and statecraft as one of its principal themes. In Tibet, the genre is referred to as "treatises on worldly affairs" ('jig rten lugs kyi bstan bcos or simply lugs kyi bstan bcos), and is associated with the Sanskrit Arthaśāstra literature, and perhaps more especially, with the various Nitišastra. ${ }^{7}$ Tibetan authors identify certain Mahāyānasūtras as sources for these teachings, but are particularly keen to cite works attributed to Nāgārjuna, especially the Nìtiśāstraprajñādaṇda (Shes rab sdong bu), Nitiśāstrajantupoșaṇabindu (sKye bo gso ba'i thigs pa), the fourth chapter of Ratnāvalī (Rin chen phreng ba), and Suhrllekha (bShes pa’i spring yig). The latter two works present themselves as advice on ethics and politics to a king and prince respectively. This format inspired Tibetan authors such

6 For discussion of the twin codes, especially in the Tibetan monastic context see Jansen (2014, 191-220).

7 Pathak examines a group of eight Niti texts translated from Sanskrit and preserved in Tibetan (1974, 25-45). 
as 'Ju mi pham rgya mtsho (1846-1912), who composed his own "Treatise on Kingship" (rGyal po'i lugs kyi bstan bcos). ${ }^{8}$ The principal aim is to inform the ruler of religious responsibilities, but his estate is presented entirely in terms of the worldly domain ('jig rten): i.e. drawing from the worldly-other-worldly distinction.

The ruler in the case of 'Ju mi pham's work was Ngag dbang 'jam dpal rin chen, ruler of the territory of Derge ( $s D e d g e$ ) in Eastern Tibet. Apart from reference to this ruler in the short colophon, ${ }^{9}$ information about the historical background is almost totally lacking. Quite apart from their desire to conform to literary norms, Buddhist writers such as 'Ju mi pham also wished to project the universal appeal and relevance of their message, something that was best achieved by lifting it out of a historically and geographically specific context. For the most part, such works refer to an idealised vision of society, based upon the four-fold Indian varna-system, and are often almost entirely devoid of explicit details regarding their actual setting. ${ }^{10}$ These works are, however, clear about their sources. In the colophon, 'Ju mi pham cites a long list of texts, including, among others, the aforesaid works of Nāgārjuna, as well as the Suvarnaprabhāsottamasūtra (Sūtra of Golden Light). Thus, despite the tendency towards the universalistic portrayal, these authors present us with evidence that allows us to identify the fonts of their inspiration and plot historical routes of communication for schemes such as the worldly-other-worldly one.

\subsubsection{Interreligious Relationships}

Seyfort Ruegg's earlier remark regarding the way that the worldly-other-worldly opposition has "served as an organizing principle" alluded to its appearance at the interface between Buddhist and non-Buddhist traditions. Kleine proposes that the scheme has, since ancient times, "served as an apologetic strategy by which Buddhists demonstrated their superiority over other cults while accepting religious plurality" $(2013,18)$. Evidence of this appears, for instance, in China, where the worldly-other-worldly distinction (shijian-chushijian) played a role in

\footnotetext{
8 For more discussion of this work see Hartley (1997). A translation, entitled "Mipam's Treatise on Royal Ethics," by José Cabezón, is also forthcoming (no publication details yet available).

9 See pp.197-200 of the Shes rig dpar khang edition.

10 This is not to dismiss the issue of classes and outcastes as irrelevant to the Tibetan situation. But we refer here to a literary reimagining of the culturally distant and socially distinct Indian system based on the varna model.
} 
a re-characterisation of Buddhism's relations with other traditions. From the $5^{\text {th }}$ century CE, in elite discourses, the doctrine of the Three Teachings (sanjiao) was promoted. This conceived of the religious landscape as a single conceptual unit, within which Buddhism, Daoism, and Confucianism were all necessary and harmonious components (Gentz 2013, 125). From the $6^{\text {th }}$ century onwards, however, the growing self-awareness and self-assertiveness of Buddhism brought about what has commonly been interpreted as a "strong tendency towards Indianization" (Gentz 2013, 125). Rejection of the doctrine of the Three Teachings in some quarters expressed itself through increased reliance upon the language of the worldly-other-worldly distinction: Buddhism was other-worldly, whereas Daoism and Confucianism were branded "worldly." In Buddhist polemical literature, in response to Daoist criticisms of Buddhism, Daoism is accused of concerning itself solely with the "worldly" realm (Gentz 2013, 125).

As well as being used to characterise relations between differing religious traditions, the scheme has been deployed assiduously in the branding of specific classes of the unseen community. Buddhist literature served as a medium for the export of various specifically Indic gods and spirits classified as "worldly" (i.e. in doctrinal terms, understood as belonging to the samsāric rather than the nirvānic side of the binary). Although scholars occasionally attempted to place certain native deities among the ranks of the other-worldly, the more usual approach seems to have been to consign indigenous deities to the category of the worldly, as happened, for example, with the kami in medieval Japan (Kleine 2013, 18). ${ }^{11}$

The division between the worldly deities ('jig rten gyi lha) and other-worldly deities ('jig rten las 'das pa'i lha) is particularly well established in Tibet. According to the standard narrative, it was necessary, during the $8^{\text {th }}$ century, for the Indian master Padmasambhava, to "tame" numerous worldly gods (i.e. indigenous deities), many of which were then forced to swear service as "protectors" (srung ma and chos skyong) of the Dharma. ${ }^{12}$ The language of the division can be traced back to the imperial period $\left(7^{\text {th }}-9^{\text {th }}\right.$ centuries), as evidenced by

11 As exception to this, noted by Kleine, is that during the Japanese Heian period (794-1185) attempts were made to identify various kami with emanations of Buddhas and Bodhisattvas (2013, 18, n. 31).

12 For the first and still perhaps most detailed study of the protector deity phenomenon see René de Nebesky-Wojkowitz's 1956 work, Oracles and Demons of Tibet: The Cult and Iconography of the Tibetan Protective Deities. 
stele inscriptions from the era. The 'Phyong rgyas inscription (ca. 797), ${ }^{13}$ which celebrates the reign of Khri srong lde btsan, refers to the Buddhist tradition he is credited with championing as "the Benign Other-worldly Dharma." ${ }^{14}$ Clearly, this served to distinguish it from some "worldly" other(s). In a similarly early text, ${ }^{15}$ celebrating the foundation of the De ga g.yu tshal monastery, there is reference to "all of the worldly gods and nāgas."16

Commonly speaking, in contrast to the other-worldly deities, the worldly gods are portrayed as "malicious, excitable, and easily offended" (Mengele 2010, 111). References to these gods and practices devoted to them have often appeared in writings on the precepts accompanying the taking of refuge in the Three Jewels. The standard advice, such as that offered by Grags pa bshad sgrub (1675-1748?), has been ${ }^{17}$ : "One is not to take refuge in worldly gods in any long-term sense. However, this does not preclude reliance upon them for the sake of achieving a short-term improvement in one's condition(s), just as someone who is afflicted by illness will rely upon a physician." 18

As in the case of the varna-based social model, Tibetan authors have generally inserted details from an Indian setting into these passages. Hence, most commonly in this context, the worldly gods cited are the likes of Brahma and Indra, ${ }^{19}$ figures which might have had limited relevance to the Tibetan readership. ${ }^{20}$ Occasionally, however, both Indic and indigenous deities are explicitly mentioned, such as by 0 rgyan 'jigs med chos kyi dbang po (rDza dpal sprul rin po che, 1808-1887) in his Kun bzang bla ma’i zhal lung:

Once one has gone for refuge in the Buddha, it is said that one should not prostrate oneself before gods who are still migrating through samsāra: gods of the non-Buddhist tìrthikas, such as Śiva and Viṣnu, are not free from their own sufferings within saṃāra. One should also not regard powerful worldly gods and spirits such as the "regional

13 This and the other imperial-era passages cited appear on the Old Tibetan Documents Online website (see bibliography).

14 'jig rten las 'das pa'i chos bzang po (line 29).

15 Text ITJ 0751.

16 'jig rten gyI lha klu thams cad (line 37).

17 In his work entitled: Byang chub lam rim chen mo’i snying po bsdus pa rje’i dgongs gsal dgyes byed mchod sprin.

18 'jig rten pa'i lha la phugs kyi skyabs su bzung nas skyabs su mi 'gro ba yin gyi / 'phral gyi mthun rkyen sgrub pa'i ched du re bltos byed pa mi 'gal te / nad kyis btab pas sman pa la re brtos byed pa bzhin no (Grags pa bshad sgrub 2009, 59).

19 For a discussion on viewing these as "pan-Indian" deities, shared by Buddhism and other religions see Seyfort Ruegg (2008, 19-29).

20 Deities bearing the same names do appear in Tibetan protector deity practices. However, in the context of taking refuge, the reference is to gods who belong to the foreign (i.e. Indian) setting. 
deities" (yul lha) and the "site-owners" (gzhi bdag) as sources of refuge beyond this life, then prostrate to them, making offerings and the like. ${ }^{21}$

Two groups of gods (i.e. foreign and indigenous) are acknowledged, but the message is that both occupy the same category, and that the worldly-otherworldly distinction is applicable, irrespective of cultural setting. Their subordinate status is reaffirmed, but no attempt is made to dissuade the propitiation of these worldly gods. Belief in the power and usefulness of these beings is encouraged, although strict boundaries are delineated: they cannot help in matters beyond the present life.

References to the worldly deities' efficacy go back to imperial times, as attested in the passage in the aforesaid De ga g.yu tshal text: "As this manifestation of the peace treaty's excellence is something known and verified by the Three Jewels and all the worldly gods and nāgas it is hoped that (the agreement and the political order) will steadily endure forever." 22 Here it is both the Three Jewels and the worldly deities that are solemnly invoked to bear witness and guarantee observance of a peace treaty, thereby securing political order. ${ }^{23}$ The rest of the text seems to indicate that this evocation of the worldly beings is necessary due precisely to their jurisdiction over mundane matters.

In general terms, the view is that in contrast to the other-worldly deities, the worldly gods concern themselves with mundane affairs and function on a far more "human" level. Hence, they can be manipulated to serve ends which from the other-worldly perspective may be judged as of short-term value or even unworthy. This does not, however, mean that practices associated within the class marks any sort of divide in the Tibetan situation between "higher" monastic Buddhism and village Buddhism. Authors, even those from the most monastically-inclined Gelug ( $d G e$ lugs) school, have produced detailed works on the taxonomies and collected biographies of protector deities. ${ }^{24}$ Similarly,

21 sangs rgyas la skyabs su song nas 'khor bar 'khor ba'i lha la phyag mi btsal zhes bya ste / phyi rol mu stegs pa'i lha dbang phyug dang khyab 'jug la sogs rang nyid 'khor ba'i sdug bsngal las ma grol ba rnams dang / gzhan yang yul lha dang gzhi bdag la sogs pa 'jig rten gyi lha 'dre mthu bo che rnams la phyi ma’i skyabs gnas su bzung nas phyag dang mchod pa la sogs pa mi bya (rDza dpal sprul rin po che 2003, 176).

22 mjal dum gyI legs pa chen po mngon sum du mdzad (37r2) pa 'dI dkon mchog gsum dang / 'jig rten gyI lha klu thams cad kyis kyang mkhyend cIng gzigs pas na / nam du yang myI 'gyur zhing brtan bar smond to.

23 The peace treaty in question appears to be the Sino-Tibetan one of 821-822.

24 Of the most celebrated we find Dam can bstan srung gi rnam thar by Sle lung bzhad pa'i rdo rje (1697-1740) and bsTan srung dam can rgya mtsho'i mtshan tho by Klong rdol ngag dbang blo bzang (1719-1794). 
monastic authors through the centuries have helped create a whole tranche of ritual literature devoted to them. Generations of monastics have also actively participated in rituals dedicated to various worldly gods, including some that mirror the practices directed to the other-worldly beings, such as the consecration (Tibetan: rab gnas, Sanskrit: pratișthā) of images, representations, and cairns associated with those gods. ${ }^{25}$

Aspects of Southwold's description of practices in Sri Lanka (1978, 364-365) resonate with those of Tibet. As in Tibet, worldly gods may be presented as guardians of religion, invoked in overtly Buddhist practices, and their representations can be found close to Buddhist temples. Monastic communities indulge the practices. Southwold's informants explained that: “The gods have power only in worldly (laukika) matters, and one chooses to relate to them only for worldly ends" (1978, 365). It seems clear that the boundaries and hierarchy intrinsic to the worldly-other-worldly division have been internalised by members of village communities as much as monastic institutions. Propitiation of these gods is acceptable on the grounds that it does not challenge the Buddhist order and the superiority of the other-worldly values. The sense, for the general population, of the remoteness of the higher spiritual goals is used to justify engagement with these gods. This engagement may be spoken of in apologetic tones, and practices portrayed as a form of addiction. There are also parallels between characterisations of the Tibetan protectors and the Japanese kami. The belligerent nature, as well as the punishment of communities (through the visitation of natural disasters) and that of individuals (for religious infractions) which are noted for the kami (Teeuwen and Rambelli 2003, 11) resemble the character and behavioural traits commonly attributed to various Tibetan srung ma.

\subsection{Caught in the Binary Thrall}

As the worldly-other-worldly distinction has commonly been used to delineate two distinct domains (related to governance, law, and religion), some academics have drawn comparisons with various western binary frameworks. Before returning to more details of the worldly-other-worldly division, the way that these other binaries have been explained as both relevant to and perhaps helping to explain the existence of the emic distinction warrant consideration. The comparisons seem primarily to have been prompted because the worldly-other-worldly

25 For example, 'Jig rten pa'i lha rten sogs la rab gnas bya tshul which appears in rGyun mkho'i cho ga phyag len sna tshogs by Nags gtsang byams pa ngag dbang (1998). 
distinction has been used to demarcate a sphere of religion, particularly in contrast with some inferior "other" - commonly represented in academic literature as a secular, or non-religious domain. Hence, in the studies already cited, discussion about how the worldly-other-worldly distinction relates to Durkheim's division between the sacred and profane is frequent, and comparison with Luther's theory of the Two Kingdoms (Zwei-Reiche-Lehre) has also occasionally been made. Kleine suggests that another dichotomy, advanced by Luhmann is relevant. Luhmann conceives of various "function systems," each of which has its own specific binary code serving as its "main tool for internal integration and external demarcation" (Blühdorn 2000, 343), determining what is relevant to the communications that occur within the system. The specific binary code for religion, governing communication, is that of "transcendence" and "immanence." 26 Kleine proposes this can be linked to (and account for) the worldly-other worldly distinction and the aforesaid "ōbō/buppō dichotomy." He also contends that: "As contingency, indeterminacy and transcendence are fundamental problems for all human beings and all social systems, and because communication centering on the code of transcendence/immanence leads to the establishment of religion as a distinct social system, we may assume that dividing the world into a religious and a secular sphere is a potentially universal phenomenon" $(2013,12)$.

Another binary division, specifically relevant to Tibet, is the one set out by Samuel in Civilized Shamans (1993). Samuel distinguishes what he claims are two forms of Buddhism: the "shamanic" and the "clerical" varieties. Clearly influenced by the Padmasambhava subjugation narrative, Samuel believes that it is profitable to explore Tibetan religion by considering it in terms of the polarities "wild" and the "tame" (1993, 217-222). ${ }^{27}$ Although Samuel makes no claim of a direct correspondence with the worldly-other-worldly distinction, the clerical-shamanic dichotomy (and the wild-tame polarities) serve as the framework within which the distinction is interpreted. ${ }^{28}$

There is no general agreement about which, if any, of these binaries are relevant to the worldly-other-worldly distinction, and there is not a little dispute surrounding the matter. Ames and Smith both assert the relevance of Durkheim's dichotomy. But Seyfort Ruegg $(2008,132)$ criticises Ames' attempts to equate the worldly-other-worldly distinction with Durkheim's division, stating that: "Indeed, it is anything but clear how the religious phenomena in

26 Kleine (2013, 15, n. 26) renders Immanenz and Transzendenz respectively as "transcendence" and "immanence."

27 This has been reprised more recently, as he relies upon the same framework to explain the Tibetan Bon religion (Samuel 2013).

28 See Samuel (1993, 163-165) for his distinction between worldly and other-worldly deities. 
question in his article, and which are characteristic of Buddhism in Sri Lanka and elsewhere, can be made to fit the familiar, but rather over-tidy and rigid, dichotomy sacred: profane" $(2008,132)$.

Kleine (2013, 15, n. 26) also rejects the Durkheimian division here, accusing Smith (1968, 209) of confusing lokottara with "sacred" and laukika with "profane," and arguing instead that Luhmann's theories are more germane. Samuel's binary is also intended as a means of turning away from traditional categories, offering something with a "lesser weight of prior associations" $(1993,7)$.

These comparisons are not presented merely as interesting speculation, but with the distinct sense that at least one of these binary schemes can help explain the existence of the emic distinction. As the example of Kleine shows, refutation of one scheme does not indicate disenchantment with binary divisions in general, and there is no obvious questioning the limitations or validity of cross-cultural comparison of bipartite distinctions. Confidence in binary divisions and dichotomies, at least in terms of their analytical efficacy, is strong: signs, perhaps, of an implicit faith that it is through reference to bipartite structures and dichotomies that complexities can be resolved. Perhaps this is unsurprising, given the peculiar hold that the notion of binary distinctions exerts upon many an academic mind, and the almost hallowed status it appears to enjoy in some disciplines. Here, the concern may be more with comparison - the relevance and applicability of one scheme to another - than it is about the truth or falseness of the dichotomies involved, as might be the case when rhetoric itself is the subject of analysis (see Vickers 1990). However, as the process of assertion and refutation attached to the comparisons illustrates, clear attempts are made, by more than one writer, to champion a specific dichotomy, and in so doing, promote one position to the exclusion of alternatives (Vickers 1990, 149). We therefore witness what some might see as intrinsic to examination by means of dichotomous division, namely, the introduction of "privileged categories" (Vickers 1990, 148).

The promotion of a specific dichotomy, and more generally, an over-reliance upon the imposition of bipartite divisions as an analytical approach, obviously brings with it significant potential for over-simplification and distortion. Seyfort Ruegg's judgement that Durkheim's dichotomy is "over-tidy and rigid" $(2008,132)$ is acknowledgement that insistence that things adhere to a specific dichotomy may well result in implausibly clear distinctions, over-neat categorisations, and not infrequently, resolutions to complex situations that are so strikingly simple as to test the bounds of credibility. When dealing, as in the present case, with a matter as extensive as the demarcation of boundaries related to religion, the risks appears to be exacerbated. The temptation seems great for the dichotomies to expand, to the point where the parts within them are presented as jointly exhaustive, embracing almost every aspect of what 
might be termed "tradition," all facets of which can perhaps be better understood if only things can be assigned to their "correct" categories and/or considered in terms of contrastive oppositions.

Thus, for instance, at various points, aspects of what Samuel describes as tantra, shamanism, Bon, and folk traditions all find themselves in the same category. It is the promise that fresh insights (or the revealing deeper truths) that is used to justify such categorisations. ${ }^{29}$ The mere act of corralling different traditions together will often ascribe coherency and sense to the category they share: simply through association the items within the category may seem to be bound by some invisible glue of commensality. However, the fact that individual aspects (or traditions) find themselves in the same category may owe at least as much to the demands of a (pre-determined) bipartite system, with its limited options, as it does to careful examination of the data. The exercise of categorising traditions according to such dichotomous schemes also necessarily calls for a high degree of abstraction and generalisation: the selectivity of data felt to be relevant to the categorisation can encourage the "distillation" of specific traditions. In Samuel's bipartite scheme, for instance, the clerical and shamanic represent two distinct orientations, and this seems to warrant the reduction of all religious expression and activity to a set of fundamental psychological urges (the wild and the tamed). Following this, it becomes valid to characterise whole religious schools, such as the Gelug, as predominantly clerical, and others, such as the Nyingma ( $r$ Nying $\mathrm{ma}$ ), as predominantly shamanic (Samuel 1993, 10). An eagerness to project uniformity necessarily leads to some disregard for internal variation, and risks side-lining complicated individual stories. Furthermore, the reductive process that brings about these characterisations almost inevitably involves some separation of traditions and practices from their social-cultural and historical context to facilitate abstract appraisal. The general perils associated with this reductive approach are surely only heightened when attempts are made to identify cross-cultural correspondences so that one may engage in trite comparisons.

The various schemes mentioned in this section all ascribe deep roots for their binary divisions. Durkheim's dichotomy has regularly been referred to as a universal. Luhmann's division is usually described as an embedded code. Even Samuel, who refers at one point to his categories as "conceptual tools" $(1993,8)$, ultimately seems to traces them to deep-seated psychological proclivities. The

29 Samuel's scheme allows him, for example, to combine the seemingly elemental with the lofty, as he depicts the highest aim of Mahāyāna Buddhism, i.e. the achievement of full enlightenment, as a quest for "the ultimate shamanic power" $(1993,557)$. 
idea that these binary divisions represent some form of underlying or natural order, only discernible (and verifiable) in its manifestations, recommends that investigation be confined to deciphering how systems and processes work within them. Questions about the roots of these non-emic binaries are deflected, perhaps increasing the chances of falling back, in an uncritical fashion, on the language of universality and natural order. Durkheim's division has been attacked for its Eurocentrism, and its lack of universality has been convincingly demonstrated in relation, among others, to traditional religions in Africa and Australia. Despite Kleine rejecting the equation of the worldly-other-worldly categories with those of Durkheim, he is still prepared to claim that the division of a religious and a secular sphere is a "potentially universal phenomenon" (Kleine 2013, 12). It is difficult to see how the notion of universality for a religious-secular divide is any more plausible than it is for a sacred-profane one. It might also be observed that the presumption that cross-cultural correspondences are ultimately attributable to universality, deeply embedded codes, or binary sets of psychological orientations does not act as the greatest incentive for investigating the routes of transmission or the role of human agency in the historical diffusion of binary schemes. ${ }^{30}$

\subsubsection{Buddhist Binary Abstractionism}

It could well be remarked that for those who are committed to binary comparisons, but have reservations about supposed correspondences between binary divisions from spatially and/or chronologically remote cultural settings, Buddhism has plenty of its own that would seem ideal for comparison. Binary schemes are integral features of Buddhist thought, as attested by, among others, the fundamental samssāra-nirvāna dichotomy. Traditional scholarship, especially within Mahāyāna schools, has long engaged in examining the relations between different Buddhist schemes - binary or otherwise. Tibetan religious thinkers, in their eagerness to present theirs as a system in which Mahāyāna and Vajrayāna were fully integrated, displayed great enthusiasm for identifying correspondences between different schemes and classifications. There is at least, therefore, a traditional precedent for considering how basic structural elements within Mahāyāna Buddhism are related, albeit with a far higher degree of circumscription involved than in contemporary academic activities in this area.

30 The lack of a role for human agency is a common criticism of Luhmann's theories. 
In his study of the worldly-other-worldly division, Seyfort Ruegg remarks upon the discrepancies between etic and emic categorisations. He favours the idea of a common substratum for explaining various similarities between Hindu and Buddhist traditions, arguing that the substratum model is more useful than the borrowing paradigm. His study notably engages in much analysis of correspondences and links between different elements within Buddhism, and involves 'looking for 'emic' categories rooted in the very dynamics of Buddhist thinking” (2008, 135). Deliberating about relations and interactions between schemes within the tradition - one that is presented as a bounded system would strike many as an eminently more sensible approach than musing or disputing about vague cross-cultural correspondences. Seyfort Ruegg takes certain core concepts of Mahāyāna and Vajrayāna, such as the emptiness, and applies them to the laukika-lokottara (worldly-other-worldly) distinction. In terms of the binary schemes, he also points to possible parallelisms between pairs including lokottara-laukika, paramārtha-samvrtiti (levels of truth), and jñāna-samaya (forms of knowledge/wisdom) (2008, 151, 186), then reflects upon them and their implications. Seyfort Ruegg's sophisticated analysis does not confine itself to binary schemes, but still he manages to resist the type of erudite comparison proffered by Kleine, who distinguishes between what he says are two forms of transcendence that can be drawn from Luhmann system, and argues that these, together with Luhmann's notion of immanence, should be viewed as related to the theory of the three-fold body of Buddha $(2013,17)$.

Some might feel that a degree of theorising with respect to the worldlyother-worldly distinction, such as whether, for instance, it arises in some way from the dichotomy between samsāra and nirvāna might well be in order. There is, however, considerable risk of de-contextualisation in discussions of such abstract matters. When firmly rooted in textual traditions, and points of view attributable to specific scholars, however abstract and speculative the subject matter, investigation can obviously constitute an exploration of intellectual history. And although it may well be argued that it becomes necessary for knowledgeable academics to ponder the nature of certain structural relations because of traditional literature's failure to address them directly, perhaps more could be done to clarify, in these discussions, where the line rests between what traditional scholars have said, and what, in theory, they might have said: a point of demarcation that is often vague in musings of such a cerebral nature.

It will seem to many that the abundance of isomorphic schemes in Buddhism means that comparison between them verges on the irresistible, and that the structural elementariness of the binary division means that discussion is always likely to gravitate towards the theoretical. But it seems necessary to look beyond the binary resemblances of some schemes to recognise important variations. Those such 
as the paramārtha-samvrti and jũāna-samaya seem only rarely to have found any place outside the domain of elite discourse (and the meditations of limited numbers of practitioners). By contrast, the worldly-other worldly distinction, as has already been established, has had definite applications beyond these bounds. Examination of the topic may therefore seem to demand more historical and sociocultural context and detail than has thus far been provided, especially when investigating the dimension of "local cults." In terms of contextualisation, more acknowledgement would seem to be required of boundaries and borders between elite culture and popular society.

\subsubsection{Accounting for Cross-Cultural Appearance: In Summary}

In the foregoing discussion, different perspectives on the worldly-otherworldly division have become apparent, particularly in relation to explaining its presence in different cultural settings. At least three ways of accounting for that presence can be identified. The divisions between them are articulated here in starker terms than in any of the works cited above. They also need not, in theory, be understood as positions that oppose each other in all respects. They can, however, be said to represent three tendencies to approach the question in different ways.

Firstly, in traditional thinking, as embodied in the Tibetan Buddhist literature, although the scheme is sometimes linked with what might be termed a concept of "Buddhist civilisation" - something that, in certain manifestations, such as in the sphere of governance, takes root in those places to which Buddhism has spread - more generally it is treated as one facet of a self-evident and selfexplanatory order. Secondly, certain academics have accounted for the scheme's cross-cultural presence primarily in terms of universal or deep-rooted, underlying patterns, seemingly innate to humanity or human society. Academics who hold such positions are obviously more inclined to engage cross-cultural comparisons, stretching beyond the bounds of Buddhist cultural settings. Thirdly, there are those who, through structural analysis, have explained the scheme as being integral to Buddhist thought, and thus, by implication at least, have accounted for its presence in different cultural settings in such terms.

Certain shortcomings with the second approach have been identified, and while the third approach, intent upon understanding internal relations between core structural features, obviously goes some way to explaining the recurrence of certain binary divisions in different cultural spheres, the discussion almost necessarily veers towards the highly abstract. One thing that these positions 
share is their tendency to speak of the worldly-other-worldly scheme itself in singular and generalised terms. Upon questioning, most would probably agree that this scheme's presumed uniformity amounts primarily to a group of common themes and strategies, which in their translation and employment in different settings may display considerable variation.

The remainder of this study will consider the worldly-other-worldly scheme embedded within the specific socio-cultural setting of Tibet. Although it admittedly deals with the topic in somewhat broad historical terms, it aims to move away from the generalised and abstract way that the scheme has often been regarded thus far. Previous studies have not sought to account for the scheme's cross-cultural appearance in terms of historical diffusion, and the processes through which ideas and schemes such as the present one have been propagated. There is, for example, no obvious scriptural blueprint or mandate for the implementing a religious-secular divide in statecraft. A corpus of Sanskrit-language commentarial works (identified above), commonly cited by Tibetans authors, have served as sources of inspiration, but creativity and adaptation have also played their parts. Translation, commentary, and personal relations between authors and rulers all signal various processes, historical communications (between individuals and literatures), networks of transmission, structures of authority, and a major role for human agency. Although none of these can be pursued in depth here, one of this study's contentions is that examining the scheme in terms of historical processes of diffusion can serve as a valuable alternative, and perhaps necessary counter, to the generalised and undifferentiated way that cross-cultural Buddhist traditions are often approached.

\subsection{The Binary Distortion of Religious History}

It may well be felt speculative cross-cultural comparisons premised upon the assumption that similar binary schemes manifest in different times and cultural settings is doomed to over-simplification and some degree of distortion. Focussing on emic schemes in individual settings may seem to bring with it some degree of reassurance. Indigenous expressions might naturally seem like more trustworthy guides to the religions, cultures, and societies in which they have featured. Before returning to the worldly-other-worldly distinction, it may be useful to reflect on the example of another Tibetan religious binary division, that of Bon and Buddhism.

The Bon-Buddhism division, while one of Tibetan origin, is also controversial. A major source of dispute has been the use of the term "shamanism" in relation to Bon. While a few continue to use the term in relation to the Bon 
tradition, this is opposed by many others. ${ }^{31}$ Bjerken, for instance, explores what he sees as the concept's dubious relationship with interpretations of Tibetan practices $(2004,8-30)$. He concludes that "shamanism" is viewed by many leading Tibetologists as "inappropriate [...] for describing any aspect of Tibetan religion" (2004, 6). Early studies of Tibetan religion by foreign travellers and savants popularised a stereotypical image of two competing religious traditions - Buddhism and "ancient" Bon. Bjerken argues that Bon's association with shamanism derives from the interpretations of "amateur Orientalists" (2004, 8), with their preconceptions regarding "primitive" religion. The image feeds the tendency to view the past in terms of other simple oppositions - the struggle between the ancient and new, the native and foreign, the shamanic and the monastic. Even those who might favour characterising the past in terms of such oppositions, and believing that they might hold some truth, would probably feel instinctively that things cannot have been so straightforward: and thus it proves with the Bon-Buddhism dichotomy. Any notion of Bon as a pre-Buddhist religion, locked in a binary opposition with Buddhism, is impossible to reconcile with the current understanding of historical processes. It is now known that the critical period for the formation of the Bon religion was the $10^{\text {th }}$ and $11^{\text {th }}$ centuries, with the intervention of historical figures, particularly Shenchen Luga (gShen chen klu dga') and his followers, ${ }^{32}$ who seem to have been instrumental in transforming strands of pre-existing traditions into a monastic-based religion. Debates about whether prior to this, during the imperial period, there was a unified system known as $B / b o n$, continue. However, any sense that the Bon of later centuries represents the survival of some pre-existing and more elementary expression of spirituality is gone. ${ }^{33}$ To a large extent, Bon owes its origins to processes of interplay and exchange, and a monastic reinvention of the tradition instigated by identifiable human agents, very much in the image of its "opponent" (i.e. Buddhism).

The characterisation of Buddhism and Bon as two religious systems forming a simple binary opposition, as well as the association of Bon with shamanism and primitive religion might seem like prime examples of foreign conceptual imposition, initiated by the aforesaid "amateur Orientalists," and perpetuated in popular literature. But the picture is more complicated. Early foreign travellers and writers picked up on the propensity of both historical Buddhist authors and

31 See note 34.

32 This issue is explored by Martin (2001).

33 In acknowledgement of the transformation, some academics distinguish between Bon, the organised religion that arose in the $10^{\text {th }}$ and $11^{\text {th }}$ centuries, from bon, the tradition(s) that preceded this. 
Tibetan popular narrative to reduce a complex picture to an elementary BonBuddhism opposition: the idea that Tibet's past could best be understood in terms of a tension between two competing spiritual traditions. Historically, while Buddhist authors have generally been keen to stress the divide, there has been considerable variation in attitudes to their supposed rival. Some have dealt with Bon in a more sympathetic fashion, whereas others have portrayed it as an "evil" religion. It is, however, uniformly represented as a single tradition. This image is eagerly accepted by adherents of Bon, who also promote the idea of that the Bon tradition constitutes an ancient continuity. Those adherents who are aware of the "primitive" connotations of terms such as shamanism, are equally keen as Bjerken to disassociate Bon from them. Accusations of primitiveness are stock features of historical anti-Bon polemic, dating from centuries before the entrance of terms like shamanism. Attempts to distance Bon from the primitive taint are also mixed with the desire of the monastic tradition to claim exclusive rights to the name of Bon. Furthermore, while there are more general problems with the concept of shamanism, the objections of some in Tibetan Studies to its usage seems to be based partly on the view that the perceived universality of the concept clashes with the image of uniqueness that they seek to maintain with respect to Tibetan religious traditions.

More recently, a subtler dimension to the evolution of the Bon tradition has arisen from analysis of imperial-era documents. It has been asserted that: "It is Buddhism, an imported metanarrative, that brings together this variety of Tibetan rituals and beliefs as an entity that can be identified, named and discussed" (van Schaik 2013, 254). That is, whatever the tradition(s) own adherents may have contributed, Buddhist thinkers and authors have been willing participants, or have perhaps even instigated the process, supplying what were probably a disparate set of practices with the coherency of a single tradition. In early polemical passages, Buddhist authors are seen to criticise, in specific terms, certain Tibetan practices, without attaching them to any named tradition. ${ }^{34}$ Conversely, in post-imperial works, the same practices - most notably sacrifice - are attributed to Bon. In the early passages, there is emphasis upon Buddhism as the "benign Dharma of the gods" (lha chos bzang po), which is contrasted with the "cruel" nature of these practices. There is therefore a sense of Buddhist writers engaged in a process of self-definition which involves creating some religious "other." The role of the binary structure here, in contributing towards a coalescing of identities, organised around contrastive and often extremely stereotyped opposition, cannot be ignored.

34 For further discussion see van Schaik (2013). 
This example serves as a reminder (if any were required) that contemporary academics, seeking cross-cultural correspondences are not the only ones who may be guilty of resorting to over-simplified binaries to explain or resolve complex situations. The creation of the Bon-Buddhism dichotomy is one in which both Tibetan tradition and foreign observers can be said to have colluded. The idea that this represents a dichotomous opposition, organised around polarities, is also not foreign to the indigenous setting. However, these polarities are of a crude, value-laden variety - "good-evil," "civilised-uncivilised," "compassionate-cruel" - rather than analytical. Their propagandistic quality reminds us of the type of popularist rhetoric that may emerge in any society. It is the partiality and unreliability of these divisions and categorisations that should be remembered as we return to consideration of the worldly-other-worldly distinction.

\subsubsection{The Worldly and the Unwieldy}

In traditional Tibetan literature, the coherence of the worldly and other-worldly categories is taken as given. Academic analyses of this emic division are also inclined to be somewhat trusting with respect to its logic and the integrity of its categories. In the case of the worldly category it may well be questioned whether this trust is well founded.

The terminology of the Tibetan "worldly-other-worldly" division hails from the early stage of translation, during the imperial era. The compound structure of "worldly" ('jig rten) - in contradistinction to which stands the "other-worldly" ('jig rten las 'das pa - literally: "passed beyond the world") - is a translation term, assembled from Tibetan components, which denote "locus" (rten) of "destruction" ('jig $p a$ ), and is based upon a Buddhist Sanskrit etymology, which refer to world's impermanent nature. ${ }^{35}$

35 The process of translating religious and technical vocabulary from Sanskrit to Tibetan purported to follow the Sanskritic nirukta ("etymologies") tradition. The Tibetan terms, while new, were therefore supposed to be rooted in august Sanskrit etymologies. But as Birgit Kellner points out (personal communication), the particular gloss given to the Tibetan rendering of "world" ('jig rten) is based on the idea that its Sanskrit equivalent loka is derived from lujyate "it is [bound to be] destroyed." But the Sanskrit root *luj for this term appears to be fictitious, and in the view of Michael Hahn, the "destruction" reading was probably based on the idea that this fictional root was a variant of $r u j$, "to break.” Hence, rather than simply describing 'jig rten as a Tibetan term based on a Sanskrit etymology, Birgit Kellner prefers to characterise it, more precisely, as a "Buddhist hermeneutic etymology of the Sanskrit term loka.” These points about Sanskrit "etymologies," also draw attention to another facet of the manufactured nature of the terminology and concepts relating to the worldlyother-worldly distinction. 
Another native term, srid $p a$, which was also co-opted to serve as a translation term for bhava ("becoming") in the context of the Twelve Links of Dependent Origination (Pratityasamutpāda), is also used, more generally, to signify "existence" and "world." Srid pa does not appear to have been a newly created term, but one chosen as the translation equivalent for bhava due to its prior denotation of birth and creation. Therefore, 'jig rten gave a new Buddhist gloss to "world" that seems to have contrasted diametrically with the associations of its pre-existing indigenous counterpart. Furthermore, the creation, during the era of translation, of terminology to convey the notion of two separate (worldly and other-worldly) domains does not appear to have intended to displace any earlier vocabulary. Instead it seems to have been necessitated by the absence of any terminology and concepts distinguishing between two spheres (be they religious and secular, or transcendent and immanent).

Looking beyond the translators' imprints, scrutiny of the worldly category's contents may seem to erode the sense that it represents the unmediated expression of some "universal" binary, as well as revealing other shortcomings. On a cursory level, a parallel may be drawn between this worldly category and that of the animals, which Foucault, following Borges, cites as having supposedly appeared in a "certain Chinese encyclopaedia" (1970, xvi). ${ }^{36}$ The latter is reported to have divided animals into:

(a) belonging to the Emperor, (b) embalmed, (c) tame, (d) sucking pigs, (e) sirens, (f) fabulous, (g) stray dogs, (h) included in the present classification, (i) frenzied, (j) innumerable, (k) drawn with a very fine camelhair brush, (1) et cetera, (m) having just broken the water pitcher, (n) that from a long way off "look like flies."

If one were to draw up a list of items that the "worldly" label is most commonly attached to in works by Tibetan Buddhist writers, it could include: (a) statecraft (b) folk-tales, (c) local deities, (d) certain forms of meditative concentration, (e) agricultural work, (f) non-Buddhist religions and systems (Hinduism, Confucianism, etc.) (g) the cosmos, (h) marriage, (i) arts and technologies, (j) physical geography, (k) sex, (l) disappointment at loss, ${ }^{37}$ (m) celebrations and parties, (n) materialist philosophy.

36 As Foucault acknowledges, this list is pure literary invention.

37 That is, one of the so-called "eight worldly-concerns" (Tibetan: 'jig rten chos brgyad: Sanskrit: aștau lokadharmāḥ) personal concerns about gain, loss, status, disgrace, censure, praise, pleasure, and pain. 
The basis of Borges' category must, in some sense, be distinguished from the category itself. Even a bizarre concept such as the "emperor's animals" can provide the "logic" necessary for the formation of a homogenous taxonomy. It would also be pointless to deny that the mere act of categorisation is invested with power. Even an apparently random group of items may, through common juxtaposition or association, eventually seem to "belong" together. As Foucault (1970, xvii) remarks: "We are all familiar with the disconcerting effect of the proximity of extremes, or, quite simply, with the sudden vicinity of things that have no relation to each other; the mere act of enumeration that heaps them all together has a power of enchantment all its own."

Similarly, the worldly category also has a basis and binding logic. From the soteriological viewpoint adopted by Buddhist thinkers and writers, the "worldly" forms a coherent and real category. From any other angle, this may simply strike us, as with Borges' list, as a curious way of looking at things and a set of bizarre juxtapositions.

Despite the blanket designation "worldly," the varied items in the category are associated with certain different perspectives. The category ranges from elements that religious authors would contend are: i) negative, and always to be shunned - such as the "eight worldly concerns"; ii) neutral, and permitted for particular individuals in certain situations - such as, agricultural work and marriage; and iii) positive or desirable for spiritual progress requirements such as samādhi concentrations prior to reaching the ârya stage. In no text (to my knowledge) are these subdivisions explicitly spelt out, although anyone reasonably well versed in textual knowledge would readily confirm their existence. The general lack of interest in internal divisions perhaps highlights what might already seem obvious. Namely; the worldly category does not derive from some theory of resemblance, or a careful exercise in taxonomical arrangement. The category comprises an almost random collection of elements, thrown together solely because of the universal act of bifurcation, demanded by the binary scheme. The scheme itself is supremely disinterested in variation. It is also intended not so much as description as a judgement with respect to the world(ly). The scheme's only logic is to create a hierarchical division in which the worldly is projected as inferior to the other-worldly. In terms of managing relations with other practices and traditions, there would seem to have been a positive side to this. Through a combination of religious ideology, reference to Indic precedents, local reinterpretations, and pragmatic considerations, the scheme has contributed, in different settings, to relatively tolerant attitudes regarding the continued practice of various pre- or co-existing traditions. On the other side, however, the uncompromising soteriological logic of the scheme means that the terms for admission of the various "Buddhist," "non-Buddhist," or 
non-religious, secular elements ${ }^{38}$ receiving the "worldly" designation are their subordination. ${ }^{39}$ In addition to the physical world, the term 'jig rten encompasses the personal existence of an individual. ${ }^{40}$ As the relevance of other traditions (especially Tibetan indigenous ones) is limited to "this life," the scheme can be seen to rationalise their devaluation, by denying the possibility that they have, in the terms of organised Buddhism, any truly religious dimension. As the next section explains, this is significant for one of the ways that the scheme has been employed.

\subsubsection{Strategies of Subjugation: The Unnatural Order of Imposition}

Leaving aside, for a moment, questions about the origins of the worldly-otherworldly scheme, and the integrity of its categories, we return to aspects of its application. The scheme warrants the description "cross-cultural” because it has featured prominently in a variety of cultural settings within Asia, in a common set of domains, such as governance and interreligious relations. Focussing upon the scheme's employment in these two domains is to align it closely with order and (at least in certain contexts) a degree of balance within society. Based upon this, the scheme would appear to be something that has not only been linked with visions of an ideal society, but has also played a practical role in societies' regulation. Viewed in these terms, the resemblances (vague or otherwise) between aspects of the worldly-other-worldly scheme and various ideas and models (such as the notion of a religious-secular divide) that are pertinent to the creation of the social contract and the establishment of a balance of power in social or state-settings further afield become more compelling, and the assertion of correspondences between them seems more justified. This perspective on the scheme is, however, too limited. Returning to the issue of the categorisation of deities brings to light a less than benevolent aspect of the scheme's employment.

As noted above, it has been customary for indigenous authors and academics alike to speak of the worldly-other-worldly distinction in a very generalised

38 Although there is insufficient space to pursue the matter here, I acknowledge some reservations about usage of the term "secular" in the present context.

39 The literary expression of this subordination is discussed by Seyfort Ruegg (2008, 45-56).

40 That is, "this world" ('jig rten 'di) denotes the present life, whereas the "earlier world” ('jig rten snga ma) and "future world" ('jig rten phyi ma) convey former and future lives, respectively. 
fashion, giving the impression of a standardised Buddhist division, observed and applied in an almost uniform manner. The frequent references to Indic gods and spirit categories, such as devas, yakșas, and so forth (Southwold 1978, 364; Kleine 2013, 18) add to this impression. In reality, of course, there have been variations in each cultural setting, especially with regard to deities. "Pan-Indian" gods (Seyfort Ruegg 2008, 19-29), such as Brahma and Indra, were to some extent imported into different settings as part of the Buddhist literary and iconographic traditions (particularly those associated with scripture). Hence it is not surprising that these Indic gods, or mentions of them, appear in an array of cultural settings, distinct from their original "homeland." Although this meant a new place for individual Indic gods on the walls of temple and the folios of texts, this was no guarantee that they were assimilated into popular narrative or practices. In Tibet, for instance, Brahma, or at least a god sharing his name (Tshangs pa), became the centre of a protector cult (NebeskyWojkowitz 1956, 145-153), but this was not true for all such imported deities. In a taxonomical sense, however, these gods had an important function collectively. In Tibet and elsewhere they formed the basis of a ready-made category of supernatural inferiors. It was to this category, already populated by Indic gods, that indigenous deities, be they Japanese kami or Tibetan srung ma (depending on the setting) could be assigned. In Tibet, the account of Padmasambhava bringing indigenous deities to heel approaches something of a master-narrative for the local interpretation of the worldly-other-worldly distinction. The narrative set in imperial times, talks of native deities, uniformly transformed into worldly protectors of Buddhism. But there is little real homogeneity in this category. It encompasses an unholy mixture, ranging from deities with Indic origin, to gods associated with local Tibetan geographic features (mountains and lakes), pre-imperial or imperial-era kingship cults, powerful political figures, mythical martial leaders, tribal chieftains, and numerous others, many of which are not pre-Buddhist in any sense. ${ }^{41}$

Viewed simply in terms of the ways that deities are classified, the scheme seems innocuous, and any role it might have played in history, of little practical consequence. However, behind the deity-names would seem to have lain any number of cults, practices, and belief-systems, rooted in individual communities and environments. Rather than simply noting that local deities were placed in the inferior category, and considering the constructive aspects of a scheme which has allowed the assimilation of indigenous practices into a Buddhist

41 Traditional accounts of the various origins of some of the protectors are given in works such as the Dam can bstan srung gi rnam thar, mentioned above. 
framework, it seems necessary to investigate the scheme's role in promoting a culture of subservience, and thereby helping to re-draw the religious landscape. Further exploration is required of the agents of this subordination, the background of the strategies that they employed, and the interests that this classification served, as well as who or what, beyond the deities, it was deemed necessary to subjugate. In the Tibetan case, the perhaps unusual extent of monastic involvement with the worldly elements itself must be seen in the context of this subordinating strategy. Documentation, classification, and the Buddhicisation of ritual were all ways in which a primarily monastic community could stamp its authority on popular practice: without discouraging it, the intention was to mould, channel, and regulate it. Thus, for example, the local community might be inclined to interpret epidemics, unexplained deaths, or natural disasters as signs of the displeasure of powerful mountain deities. The worldly-other-worldly division, supported by the production of narrative and ritual texts, allowed the Buddhist tradition to demonstrate its superiority in such cases. Ritual specialists might be called upon to deal with the recalcitrant deities. One such account appears in the early $15^{\text {th }}$ century hagiography of Khyung po rnal 'byor (ca.1050-ca.1140), where the protagonist was called upon to deal with problematic deities, including the potent mountain spirit, gNyan chen thang lha. ${ }^{42}$ Where spirits resisted, battle ensued, fought out partly through control of the elements. In one case, Khyung po rnal 'byor, manifesting as the fierce, horned Buddhist tantric deity Yamāntaka, finally brought the offender, ' $\mathrm{Ba}$ ' ra nag po, to his knees. Pleading for mercy, the latter said: "Great lama, I beg you to desist! My entire retinue have been killed by (your) lightning, and every one of my (religious) sites destroyed by (your) buffalo horns. And now I, coughing up blood, am on the point of death!"43

Such accounts did no harm to the personal reputations of their Buddhist central figures, but were obviously also intended to convey the power and superiority of the religion to which they belonged. The spirits are not depicted as rogue operators so much as rulers at the centre of parallel power structures, and there are frequent references to pacts between them and the local human population, who engage in sacrificial practices in their honour. However, in the ultimate expression of submission, spirits such as 'Ba' ra nag po were finally compelled to adopt the lay (upāsaka) Buddhist vows. This cannot be understood purely as

42 This account appears in Khyung po rnal 'byor gyi rnam thar (Nam mkha' bsam grub rgyal mtshan 1996, 52-54).

43 bla ma chen po de ltar mi mdzad pa zhu / nga'i 'khor thams cad thog gis bsad / ma he'i rwas gnas thams cad bshig / da nga khrag skyugs nas 'chi bar yod (Nam mkha' bsam grub rgyal mtshan 1996, 52-53). 
metaphor, the announcement or reassertion of Buddhist hegemony involved the acceptance of Buddhist regulation of local ritual dominions, or their dismantlement.

Tibetan landscapes, both literal and literary, are strewn with such narratives. The negotiation between the organised Buddhist religion and more localised, unregulated ritual systems have either spawned or at least helped standardise various sets of symbols, vocabulary, and mediums, such as the binary distinction between "white" and "red" (dkar mchod and dmar mchod) offerings - respectively, dairy-based and slaughter-based. Each deity is said to prefer one or the other form of propitiation, and these are to some extent indicative of their supposed relations with organised Buddhism, which can range from an enthusiastic embrace to a begrudging acceptance of its principles and supremacy.

There would seem to be significant cross-cultural correspondences in the way that Indic deities have been retained and amalgamated with native deities to construct a single category of worldly gods. However, there would seem to be more to this than just creating the image of a homogenous, subordinate pantheon. In the way that the scheme has been applied, there is evidence of processes (and perhaps a common set of strategies) for managing and manipulating systems of practice related to indigenous deities. This puts a different complexion on binary divisions such as the worldly-other-worldly distinction. As already demonstrated in terms of the Bon-Buddhism division, what might superficially appear to be a straightforward and somewhat neutral distinction, that helps explain the religious or historical landscape, revealed itself instead to be one derived from complex processes, involving the encounter between organised religion and pre-existing or co-existing traditions. Somewhat contrasting with the notion of the worldly-other-worldly distinction as some "natural" articulation of religion, favourable to expressions of religious plurality, we see it as an extremely partisan, and in certain aspects highly contrived hierarchical division, employed in the projection of power. The concept of privileged categories might well be seen as an appropriate one here.

\subsection{Influences of the Worldly-Other-Worldly Scheme in the Tibetan Social Realm}

In recent decades, Tibetan Studies specialists have grown increasingly aware of the importance of local traditions, particularly mountain-deity cults. The local framework, while limited in its scope, does at least offer some alternative to the view that the Tibetan religious world must be described in terms of a 
straightforward binary of monolithic traditions - namely, Buddhism and Bon. The major part, already outlined, that the Bon- Buddhism binary seems to have played in creating the religious "other" contrasts markedly with what we see in the worldly-other-worldly division. Apart from projecting the idea of Buddhism's supremacy, this scheme seems disinterested in depicting any single opposition, especially one which could be characterised as religious. The apparent randomness of the worldly category's contents in Tibet makes more sense when one begins to appreciate the extent to which it has been contrived by scholarly discourse, dominated by other-worldly value-judgements. Hence, one might wonder how much impact the division has had outside the scholarly domain. Seeking to clarify this offers an opportunity to demonstrate how the worldly-other-worldly distinction can be discussed without resorting to a blurring of boundaries or launching into a realm of abstraction.

Seyfort Ruegg depicts the worldly-other-worldly scheme as "dynamic" $(2008,83)$. Part of his grounds for this contention seems to be that the scheme allows worldly beings (gods, etc.) to progress to the other-worldly level. He may be right to posit "upward mobility" in terms of theory. But this has little relevance to the actual usage. Neither in the ritual world, scholarly discourse, nor popular belief can it be said that there is concern with charting the "spiritual development" of gods and spirits. Both they and the classes they belong to are invariably viewed in static terms. Hence, the scheme has primarily been used to foster the idea of a fixed order. The worldly gods, for instance, are locked into their subordinate position, and maintain a set of frozen relationships with both the other-worldly beings and their human clients. Hagiographical writings, as we have seen, often include accounts of historical figures subjugating individual gods. Ritual works are predicated on the veracity of these accounts. Both hagiography and ritual works feature prominently at the monastic-lay interface, and have served as channels through which the notion of a "worldly" order - specifically bearing the message that the worldly gods, while effective, are inferior - could enter popular consciousness from the literary domain.

A contemporary example of the use of the scheme, and the relation between the scholarly domain and popular understanding, comes in the form of one of the most contentious issues, especially among the Tibetan diaspora, in recent years. This relates to the protector deity Dorje Shugden (rDo rje shugs ldan) or Dolgyal (Dol rgyal). The issue of whether this is a worldly or otherworldly being divides opponents and supporters of practices associated with the cult. I do not pretend that the whole issue can be reduced to an argument about the worldly-other-worldly designation. However, the reliability and status of the deity are perceived as crucial issues, and arouse great passions. The 
worldly-other-worldly debate serves as a framework for the debates. ${ }^{44}$ The basis of the division is primarily a matter for scholarly discourse. Uneducated and doctrinally illiterate Tibetans, in my experience, usually admit that their understanding of this debate, and perhaps also the concept of the "otherworldly," is decidedly hazy. But they are still keenly aware that in the current context, the term "worldly god" ('jig rten gyi lha) refers to an inferior category, and can therefore be interpreted as a pejorative designation. That is: awareness of the subordinating function and disparaging usage of the scheme's terminology can be separated from contextual details, and communicated primarily through the tone of everyday exchanges.

While illustrating how the language of the scheme can be relevant to the world's "everyday affairs," the above example still belongs firmly to what might broadly be described as the province of religion. To better understand the degree of the scheme's influence in popular culture, however, we must look beyond domains that would usually be described as "religious" (either in the sense of organised religion or cultic practices). Perhaps unsurprisingly, in documents written for a monastic audience, the authors regularly seek to distinguish their community and activities from those of lay persons by applying the label "worldly" to the latter. Hence, the lay person is represented as the "worldly householder" ('jig rten khyim pa), ${ }^{45}$ or even simply as the "worldly one" ('jig rten pa). ${ }^{46}$ The same is true for common activities, often referred to as "farming and the like, the activities of worldly ones" (so nam sogs 'jig rten pa' $i$ bya $b a) .{ }^{47}$ Similarly, in hagiography, an especially well-rehearsed scenario involves the protagonist departing home for a monastic existence. Ignoring the distressed cries of his parents, who plead with him (sometimes their sole heir) to stay and perform his reproductive duties, and thereby protect the family inheritance, he dismisses concern for all such things as "worldly." ${ }^{48}$ Even in literature with broad popular appeal, religious characters such as Milarepa can be expected to make use of the worldly designation in their disavowal of the mundane, such as when he declares: "I do not want worldly sons." 49 The account of

44 For further details on the controversy see Dreyfus (1998).

45 From the Monastic Guidelines ( $b c a^{\prime}$ yig) of bKra shis lhun po monastery, cited in Jansen (2014, 133).

46 This appears in the Monastic Guidelines of rNam rgyal grwa tshang (Jansen 2014, 165).

47 From the Monastic Guidelines of sKu 'bum byams pa gling (Jansen 2014, 179).

48 See, for example, the biography of Khyung po rnal 'byor (Nam mkha' bsam grub rgyal mtshan 1996, 6-7).

49 'jig rten gyi bu tsha nga mi 'dod. This is cited in Kun bzang bla ma'i zhal lung (rDza dpal sprul rin po che 2003, 84). 
forsaking the worldly, household life is immediately recognisable as one modelled upon the biography of the Buddha, and there are numerous examples in Tibet of monastic writers, or those wishing to project a monastic set of values, who have liberally employed the same, or a comparable set of "worldly" labels. As Buddhist authors outside Tibet have drawn from similar sources of inspiration, it is unsurprising to encounter similar passages in other literary traditions. But two important observations can be made about the Tibetan usage. The first is about how this labelling relates to "real life": however dismissive the language, the community and activities labelled as worldly are essential to the survival of the monastic life. Hence, if this message truly seeks to discourage engagement in reproduction and economically-motivated industry, the intended audience would seem only to be a portion of the population. Members of the other (lay) community, it might be presumed, would remain oblivious to the literature that employed this labelling, or if exposed to it, would recognise that the message was aimed at a monastic audience. That is, one could imagine that the language has had limited currency outside the domain of literary representation and religious narrative. I would argue, however, that quite to the contrary, this language has been embraced by the Tibetan lay world. More recently, occasional examples of this occur in ironic employment of the designation "worldly." Thus, a collection of a traditional form of song-jousting (shags), often performed during wedding ceremonies, was entitled "the Nectarbeer Songs Revelling in the Eight Worldly Concerns” ('jig rten chos brgyad dga' ba'i bdud rtsi chang shags). This blatant subversion of religious language, in which the eight mundane sources of concern, the wholly undesirable branch of the worldly family, are celebrated, must partly be seen as the product of the modern era, in which religious scepticism can be expressed openly. But in historical Tibetan literature, the practice of applying the label "worldly" to wedding-related activities is a long one. Rather than getting married, in hagiographical descriptions, religious figures, "take pleasure in accordance with worldly custom" ('jig rten dang rjes su mthun par rol rtse mdzad). ${ }^{50}$ In fact, "that which is performed in accordance to worldly custom" ('jig rten mthun 'jug) becomes a byword for the wedding itself, and "the way of the world" ('jig

50 This term appears, for instance, in the biography of Chos rje nam mkha' rgyal mtshan in Shangs pa bka' brgyud bla rabs kyi rnam thar (Nam mkha' bsam grub rgyal mtshan 1996, 440). The terminology is intended to convey a sense of obligation. It also distances the protagonist from true engagement, implying that this may, after all, be part of a religious performance, setting the scene for the subsequent abandonment of the world. In the present case, the "pleasure" can be taken to allude both to the celebrations surrounding the wedding and the subsequent enjoyment of sex. 
rten 'gro lugs) can be a designation for the exchange of prestations prior to the wedding. Even in writings that feature no lofty individuals or overtly religious content, such as the far more sympathetic works devoted solely to the description of wedding rituals, practices are still couched in these "worldly" terms. The label "worldly" has become so deeply embedded in the wedding vocabulary as to become almost inseparable from it, and in the minds of many, appears to define the Tibetan nuptial sphere.

Far from being confined to written literature, even illiterate lay persons can often be heard referring to matrimonial activities in this fashion. This is far more than the assimilation of vocabulary. Here monastic-inspired judgements have insinuated themselves into popular culture. This is demonstrated by the apologetic tone in which such "distasteful" matters as weddings particularly are spoken of during conversation with monks. Historically, institutional religion neither sanctioned nor officially recognised marriage in Tibet. The separation between the nuptial and monastic spheres was entire. Possible intersections, such as the presence of a monk at a wedding, have traditionally not been welcomed, and have been deemed inappropriate, both in monastic and lay terms.

The worldly-other-worldly division can hardly be viewed as solely responsible for what some might view as the discrimination against secular traditions. However, it could well be argued that the scheme has served as the primary vehicle for the imposition of a religious order, and that the designation "worldly" has, like no other, been absorbed into secular traditions and continues to be employed in a voluntary form of self-subordination. Even in the modern era, where descriptions of weddings and popular practices are plentiful, compilers and authors, still feel unconsciously compelled to attach to them the label, apparently in some deferential echo from the past.

More generally, perhaps the strongest evidence of both the hierarchical imposition and secular absorption of the attitudes that the worldly-other-worldly scheme has served as a vehicle for is the absence of relevant historical literature. Despite Tibet's boast of more than twelve centuries of literary activity and a huge literary corpus, the number of works dealing overtly with secular practices, such as weddings and various other rites of passage, is pitiful. ${ }^{51}$ The primary blame for this dearth of literature surely rests with the disdainful attitudes towards them

\footnotetext{
51 Since the late 1970s in Tibet, concurrent with the rise of modern Tibetan literary movement, there has been a tremendous expansion of the range and diversity of Tibetan-language publications. There is now no shortage of texts describing traditional wedding rituals and recitations. But the exact provenance of the material they contain cannot be established. The handful of texts that can dated to earlier than the late $20^{\text {th }}$ century belies the richness and ubiquity of ritual traditions that preceded.
} 
emanating from a religious establishment. Monastic writers especially have judged them unworthy of recording and preserving, and as such have effectively confined centuries of practice almost entirely to the realm of oral literature and unrecorded history. While the emic credentials of the worldly-other-worldly distinction are indisputable, the role it has played in the literary and historical marginalisation of secular practices has been a significant one. It may have served the purposes of a religious (and chiefly monastic) community, but certainly should not be interpreted as an unbiased representation of Tibetan beliefs and practices. A crucial question arises from this. Namely, how much have these literary biases shaped our perceptions of Tibetan culture? To what extent does the picture of Tibetan cultural life as one dominated by the organised religions of Buddhism and Bon derive from our over-enthusiasm to accept the emic descriptions, as presented in a literature whose anti-secular prejudices are so blatant?

In addition to the role it has had in shaping Tibetan cultural perceptions, a second observation can be made regarding the Tibetan worldly-other-worldly division. In a religious culture inspired by the monastic ideal, and in which the tension between the householder and ascetic lifestyles would be viewed by many as intrinsic, marriage, reproduction, and concerns related to them are, predictably, regular targets of renounced invective. Here the label "worldly" acts as the most regularly employed cliché, both in Tibetan Buddhist literature and popular discourse, for those wishing to speak of marriage in dismissive terms. More generally, there are no collective terms for the life-cycle events and traditional practices that surround them, but labels such as "worldly customs" ('jig rten pa'i lugs) are commonly used to refer to them. The "worldly" categorisation and designations certainly affected the historical perception and reporting of life-cycle events, and the associated rituals in Tibet. ${ }^{52}$ Their relation to organised religion, for instance, contrasts greatly with what is found in the Hindu traditions, where religion and the rites of passage (samskāra) are generally seen as part of a unified system. ${ }^{53}$ But life-cycle rituals imply a system - a set of norms and values, centred particularly upon birth and marriage, and understandings of the individual as part of this reproductive system. It is perfectly understandable that a monastically-inspired religious culture would not wish to represent this alien system. I would contend, however, that the "worldly" characterisation, as the most common and unflattering cliche that has allowed those who are so minded (both in literary discourse and everyday

52 The exception here is the domain of death and funerary rituals, which organised religion has exercised a strong control over.

53 For discussion of the Hindu rites of passage see Michaels (2004, 71-99). 
parlance, through to the present day) to consciously erode any notion that these customs and practices belong to anything that might constitute a coherent system, or components of a separate, parallel (and by implication, rival) order. The "worldly" designation supports the characterisation of them as a disparate and perhaps chaotic mix of practices, with a barely discernible logic and lacking that most essential of sources for organised Buddhism, scriptural authority.

The research of local traditions, such as mountain-deity cults, provides an important perspective on Tibetan religious practice. It reminds us of the existence of nexuses of ritual and belief other than those centred in the monastery, and of expressions of religion that may not accord exactly with the projections of organised Buddhism. But aside from the somewhat discredited notion that Bon constitutes an entirely different form of religious expression, there is no real sense of any substantial religious "other" in Tibet. The case for advocating the reproductive nexus as this "other," or even one of the others has yet to be made, but it is one that I would propose warrants consideration. Organised Buddhism in Tibet, with its monastic-inspired ideals, has generally sought to minimise the importance of descent, kinship relations, and life-cycle rituals, and dismiss the idea that they have any religious significance. However, as numerous anthropological studies would confirm, in other societies (particularly those where the influence of organised religion might be weaker) the very same elements are regularly interpreted as constituting integral elements or even the foundations of traditional religion. If we add to this the place of poorly understood aspects of Tibet's past, such as clan-based organisation and ancestor-related practices, there would seem to be very good reasons for exploring the aforesaid elements in terms of the reproductive nexus, in the devaluing of which the worldly-other-worldly distinction appears to be implicated.

\subsection{Conclusion}

As stated in the introduction, the worldly-other-worldly division's traversing of regional, ethnic, and linguistic boundaries warrants its consideration as a cross-cultural (or perhaps, in the view of some, a transcultural) phenomenon. Partly in attempts to account for this cross-cultural appearance, certain academics have chosen to push discussion into the realm of universals (or related concepts), seeking to associate the scheme with other binary divisions - religious-secular, spiritual-profane, transcendent-immanent. The suggestion has been that, either due to the structure of human society or the human mind, the reappearance of such a division is inevitable. A structural perspective, less 
inclined towards such expansive and speculative generalisations, is taken by Seyfort Ruegg, who contemplates the way that the worldly-other-worldly division is related to other schemes within Buddhism. These studies also give the impression that the scheme has generally been employed in a relatively constructive fashion, by stressing how it has been used in the areas of governance, interreligious relations, and the integration of non-Buddhist traditions. Throughout, there is strong tendency to approach the scheme in a generalised fashion. Traditional sources, especially in their frequent reference to Indic elements (gods, spirits, and a varna-based social model), do nothing to deter the sense of this as a single scheme, that has manifested in a uniform manner. However, academic generalisation seems to be more attributable to the aforesaid desire to explain the scheme's appearance in different settings.

The universalistic path inexorably draws one away from the specifics, not least because it forces us to move outside the realm of traceable historical and textual pathways. Concerns about the "bigger picture" also seem, in the present case, to result in a neglect for the role of human agency. There has also been a curious lack of interest shown in historical diffusion and the processes related to it, investigation of which would seem to be integral to any interpretation of transculturality.

There is no shortage of historical and cultural detail pertinent to the worldly-other-worldly scheme that might be seen to challenge the neatness of binary generalisations, and it might readily be concluded that a fascination with structures and schemes, especially binary ones, can work to the detriment of understanding historical processes, if not almost necessarily resulting in generalisation and distortion. Far greater attention to these processes is called for in terms of the worldly-other-worldly scheme. This would lead to a better understanding of how it has traversed borders, rather than trying to account for its cross-cultural appearance in static terms. However, as topics of analysis, cross-cultural flows themselves, like schemes, may become subject to reification. On one level, it seems necessary to re-affirm the presence of borders, as abstracted from specific socio-cultural setting, the scheme cannot be understood in any meaningful sense.

A second conclusion relates to our understanding of the emic nature of the worldly-other-worldly division. Allied with their image of the division as a "natural expression" (of some universal or structural feature), previous studies have not questioned the reliability of the division. This study has demonstrated that emic schemes, perhaps especially binary ones, may be just as susceptible to charges of over-simplification, artificiality, and distortion as those which are imposed from outside. Most importantly, like their etic counterparts, they may also represent highly partial perspectives and be used for the projection of 
imperious views. Thus, in case of the worldly-other-worldly division, it would seem to have been employed not merely to reaffirm the superiority of the soteriological ideals, but to subordinate non-Buddhist traditions. Specifically, it can be seen to have played a major part in an institutionalised devaluation of practices consigned to the "secular" domain. As such, the division's role in shaping both indigenous and foreign perceptions of Tibetan culture would appear to have been significant.

Finally, there is the question of why academic discussion about the worldly-other-worldly division has so veered towards the speculative and abstract. Neither the premises or the contents of the division appear to warrant this, and it seems difficult to believe that this direction would have been taken if the emic scheme involved were, for instance, a five or six-fold one. Here Blühdorn's remark about Luhmann's theories exerting "the magic of the Sirens" $(2000,339)$ seems apposite. It is hard to escape the conclusion that the alluring elementariness of the binary scheme has once more demonstrated its beguiling appeal.

\section{References}

Ames, Michael M. 1964. "Magical-animism and Buddhism: A Structural Analysis of Sinhalese Religious Systems." The Journal of Asian Studies 23:21-52.

Bjerken, Zeff. 2004. "Exorcising the Illusion of Bon 'Shamans': A Critical Genealogy of Shamanism in Tibetan Religions.” Revue d'Études Tibetaines 6:4-59.

Blüdhorn, Ingolfur. 2000. "An Offer One Might Prefer to Refuse: The Systems Theoretical Legacy of Martin Luhmann.” European Journal of Social Theory 3.3:339-354.

Buswell, Robert E., Jr., and Donald S. Lopez Jr. 2014. The Princeton Dictionary of Buddhism.

Princeton University Press, Princeton: New Jersey.

Cüppers, Christoph, ed. 2004. The Relationship Between Religion and State (chos srid zung

'brel) in Traditional Tibet. Proceedings of a Seminar Held in Lumbini, Nepal, March 2000.

Lumbini: Lumbini International Research Institute.

Dreyfus, Georges. 1998. "The Shuk-Den Affair: Origins of a Controversy." Journal of the International Association of Buddhist Studies 21.2:227-270.

rDza dpal sprul rin po che. 2003. rDzogs pa chen po klong chen snying tig gi sngon 'gro'i khrid yig kun bzang bla ma'i zhal lung. Delhi: Songan rinpoche (tulku pema lodoe).

Foucault, Michel. 1970. The Order of Things: An Archaeology of the Human Sciences. New York: Pantheon.

Gentz, Joachim. 2013. "Religious Diversity in Three Teachings Discourses.” In Religious Diversity in Chinese Thought, edited by Perry Schmidt-Leukel and Joachim Gentz, 123-140. New York: Palgrave Macmillan.

Gombrich, Richard. 1971. Traditional Buddhism in the Rural Highlands of Ceylon. Oxford: Clarendon Press. 
Grags pa bshad sgrub. 2009. Byang chub lam rim chen mo'i snying po bsdus pa rje'i dgongs gsal dgyes byed mchod sprin. In Grags pa bshad sgrub kyi gsung 'bum. dPal btsegs bod yig dpe rnying zhib 'jug khang (anonymous editor) Vol. 17, 18-173. Beijing: Krung go'i bod rig pa dpe skrun khang.

Hartley, Lauran J. 1997. "A Socio-historical Study of the Kingdom of Sde-dge (Derge, Kham) in the Late Nineteen Century: Ris-med Views of Alliance and Authority." MA thesis, Indiana University.

Holt, Clifford J. 1991. Buddha in the Crown: Avalokiteśvara in the Buddhist Traditions of Sri Lanka. New York/Oxford: Oxford University Press.

Jansen, Berthe. 2014. "The Monastery Rules: Buddhist Monastic Organization in Pre-Modern Tibet." PhD thesis, Leiden University.

'Ju mi pham rgya mtsho. 1996. rGyal po'i lugs kyi bstan bcos sa gzhi skyong ba'i rgyan. Dharmasala: Bod gzhung shes rig dpar khang.

Kleine, Christoph. 2013. "Religion and the Secular in Premodern Japan from the Viewpoint of Systems Theory." Journal of Religion in Japan 2:1-34.

Klong rdol bla ma ngag dbang blo bzang. 1991. bsTan srung dam can rgya mtsho'i mtshan tho. In Klong rdol bla ma ngag dbang blo bzang gi gsung'bum. Vol. 2, 461-493. Gangs can rig mdzod 21. Lhasa: Bod ljongs bod yig dpe rnying dpe skrung khang.

Martin, Dan. 2001. Unearthing Bon Treasures: Life and Contested Legacy of a Tibetan Scripture Revealer, with a General Bibliography of Bon. Leiden: Brill.

McCutcheon, Russell T. 1997. Manufacturing Religion: The Discourse on Sui Generis Religion and the Politics of Nostalgia. New York: Oxford University Press.

McCutcheon, Russell T. 1998. “Redescribing 'Religion' as Social Formation: Toward a Social Theory of Religion." In What is Religion? Origins, Definitions, and Explanations, edited by Thomas A. Idinopulos, 51-71. Leiden: Brill.

Mengele, Irmgard. 2010. “Chilu ('Chi slu) Rituals for 'Deceiving Death'.” In Tibetan Ritual, edited by José Ignacio Cabezón, 103-129. Oxford: Oxford University Press.

Michaels, Axel. 2004. Hinduism: Past and Present. Princeton: Princeton University Press.

Anonymous editor. 1998. 'Jig rten pa'i lha rten sogs la rab gnas bya tshul. In rGyun mkho'i cho ga phyag len sna tshogs, 79-81. Beijing: Mi rigs dpe sprun khang.

Nam mkha' bsam grub rgyal mtshan. 1996. mKhas grub khyung po rnal 'byor gyi rnam thar. In Shangs pa bka' brgyud bla rabs kyi rnam thar by Nam-mkha' bsam-grub rgyal-mtshan, et al., 3-62 Gangs can rig mdzod 28. Lhasa: Bod ljongs bod yig dpe rnying dpe skrun khang.

Nebesky-Wojkowitz, René de. 1956. Oracles and Demons of Tibet: The Cult and Iconography of the Tibetan Protective Deities. The Hague: Mouton \& Co.

0 rgyan tshe ring, and bKra shis don grub, comps. 1998. 'Jig rten chos brgyad dga' ba'i bdud rtsi chang shags. Beijing: Mi rigs dpe skrun khang.

Old Tibetan Documents Online (OTDO). http://otdo.aa.tufs.ac.jp/ and http://otdo.aa-ken.jp/

Pathak, Suniti, K. 1974. The Indian Nìtišāstras in Tibet. Delhi: Motilal Banarsidass.

Samuel, Geoffrey. 1993. Civilized Shamans; Buddhism in Tibetan Societies. Kantipath, Kathmandu: Mandala Book Point.

Samuel, Geoffrey. 2013. "Revisiting the Problem of Bon Identity: Bon Priests and Ritual Practitioners in the Himalayas." Journal of the International Association for Bon Research 1.1:77-97. 
Seyfort Ruegg, David. 2008. The symbiosis of Buddhism with Brahmanism/Hinduism in South Asia and of Buddhism with 'local cults' in Tibet and the Himalayan region. Wien: Österreichische Akadamie der Wissenschaften.

Sle lung bzhad pa'i rdo rje. 2003. Dam can bstan srung gi rnam thar. Beijing: Mirigs dpe skrunkhang.

Smith, Bardwell L. 1968. "Toward a Buddhist Anthropology: The Problem of the Secular." Journal of the American Academy of Religion 36.3:203-216.

Smith, Jonathan Z. 1998. "Religion, Religions, Religious." In Critical Terms for Religious Studies, edited by Mark C. Taylor, 269-284. Chicago/London: University of Chicago Press.

Southwold, Martin. 1978. "Buddhism and the Definition of Religion." Man 13.3:362-379.

Southwold, Martin. 1983. Buddhism in Life: the anthropological study of religion and the Sinhalese practice of Buddhism. Manchester: University Press.

Tambiah, Stanley. J. 1970. Buddhism and the Spirit Cults in North-East Thailand. Cambridge: Cambridge University Press.

Tambiah, Stanley. J. 1976. World Conqueror and World Renouncer: a study of Buddhism and Polity in Thailand Against a Historical Background. Cambridge: Cambridge University Press.

Teeuwen, Mark, and Fabio Rambelli. 2003. "Introduction: combinatory religion and the honji suijaku paradigm in pre-modern Japan." In Buddhas and kami in Japan: Honji suijaku as a combinatory paradigm, edited by Teeuwen and Rambelli, 1-53. London/New York: RoutledgeCurzon.

van Schaik, Sam. 2013. "The Naming of Tibetan religion: Bon and Chos in the Tibetan imperial period." Journal of the International Association for Bon Research 1.1:227-257.

Vickers, Brian. 1990. "The Dangers of Dichotomy." Journal of the History of Ideas 51.1:148-159. 